\title{
Analisa Numerik Pada Kolom Beton Pracetak Mutu-Tinggi dengan Sambungan Grouted Sleeve
}

\author{
Rizky T Amalia ${ }^{1}$, Harun Alrasyid ${ }^{1, *}$, Pujo Aji ${ }^{1}$, Muhammad A Rofiq ${ }^{2}$ \\ Departemen Teknik Sipil, Institut Teknologi Sepuluh Nopember, Surabaya ${ }^{1}$, Departemen Teknik Sipil, Universitas Muhammadiyah \\ Surakarta, Surakarta ${ }^{2}$ \\ Koresponden*,Email: harun@ce.its.ac.id; harun.ce.its@gmail.com
}

\begin{tabular}{lcl}
\hline & Info Artikel & Abstract \\
\hline Diajukan & 18 Maret 2021 & The utilization of high-strength concrete and high-strength reinforcement for precast concrete \\
Diperbaiki & 04 Juni 2021 & construction has the advantage of providing small column sizes in lower stories, and faster \\
Disetujui & construction speed compares to the normal strength of reinforced concrete. Grouted Sleeve \\
& (GS) 's mechanical connection for high-strength longitudinal reinforcement at plastic hinge \\
& zone is selected since precast column with GS connection provide similar behavior with \\
& monolith reinforced concrete columns. This research presents nonlinear analysis of seismic \\
& behavior of double-curvature high-strength reinforced concrete precast columns with GS \\
& connection at the end of the column-foundation. The column dimension is $600 x 600$ mm. The \\
& concrete compressive strength is 74 MPa. The high-strength steel bar of SD685 (Yield strength \\
& of 685 MPa) and SD785(Yield Strength of 785 MPa) are used for longitudinal and transverse \\
& reinforcement. Numerical modeling is performed using an in-house finite element software, \\
& 3DNLFEA. The results show that the prediction of the 3DNLFEA model has a good agreement \\
& with the experimental results. Yielding of longitudinal reinforcement, crack patterns that \\
& occurred, and failure of transverse reinforcement are discussed.
\end{tabular}

Keywords: precast columns, high strength

Kata kunci: kolom pracetak, material mutu tinggi, numerik, 3DNLFEA, pelelehan.

\begin{abstract}
Abstrak
Penggunaan beton mutu tinggi dan tulangan mutu tinggi untuk konstruksi beton pracetak memiliki keunggulan yaitu mampu menyediakan kolom dengan ukuran kecil pada lantai yang rendah, dan kecepatan konstruksi yang lebih tinggi dibandingkan dengan beton bertulang mutu normal. Sambungan mekanis tipe grouted sleeve (GS) untuk tulangan longitudinal mutu tinggi pada zona sendi plastis dipilih karena kolom pracetak dengan sambungan GS memberikan perilaku yang sama dengan kolom beton bertulang monolit. Penelitian ini menyajikan analisis nonlinear perilaku seismik kolom beton pracetak berkurvatur ganda dengan sambungan GS pada ujung kolom-pondasi. Dimensi kolom yang digunakan yaitu 600x600 mm. Kuat tekan beton adalah $74 \mathrm{MPa}$. Tulangan mutu tinggi SD685 (kuat leleh $685 \mathrm{MPa}$ ) dan SD785 (kuat leleh $785 \mathrm{MPa}$ ) masing-masing digunakan untuk tulangan longitudinal dan transversal. Pemodelan numerik dilakukan menggunakan rangkaian program elemen-hingga, 3DNLFEA. Hasil menunjukkan prediksi model 3DNLFEA memiliki kesesuaian yang baik dengan hasil eksperimen. Pelelehan tulangan longitudinal, pola keretakan yang terjadi, dan kegagalan tulangan transversal disajikan.
\end{abstract}

\section{Pendahuluan}

Material beton mutu tinggi, high strength concrete (HSC) telah digunakan secara luas pada bagian struktur dengan beban gaya aksial tekan yang besar seperti pada kolom-kolom bangunan. Penggunaan HSC pada konstruksi beton pracetak pada gedung bertingkat tinggi telah menjawab dua tantangan utama yaitu ukuran kolom yang besar di tingkat bawah dan kecepatan konstruksi yang rendah [1]. Penggunaan beton pracetak mutu tinggi telah dipraktekkan dalam proyek percepatan konstruksi jembatan (accelerated bridge construction) di berbagai negara karena tingkat efisiensi yang tinggi dan kualitas yang baik [2]. Namun pada zona gempa sedang hingga tinggi, perhatian khusus harus diberikan pada desain dan detail sambungan antar komponen pracetak karena bagian tersebut merupakan daerah kritis dalam meneruskan beban dan dalam menjaga stabilitas struktur [3]. Bagian kritis ini berdekatan dengan sambungan balok-kolom/pelat atau pondasi [4].

Sambungan mekanis tipe grouted sleeve (GS) telah digunakan pada jembatan yang terletak di zona seismik rendah karena dapat mempercepat periode konstruksi dan menjadi metode yang andal dalam menahan beban gravitasi. Sambungan tipe ini menggunakan perangkat kopler penyambung dua tulangan baja, dimana mekanisme transfer beban di antara kedua tulangan tersebut dilakukan melalui lekatan antara kedua tulangan, semen grouting mutu tinggi, 


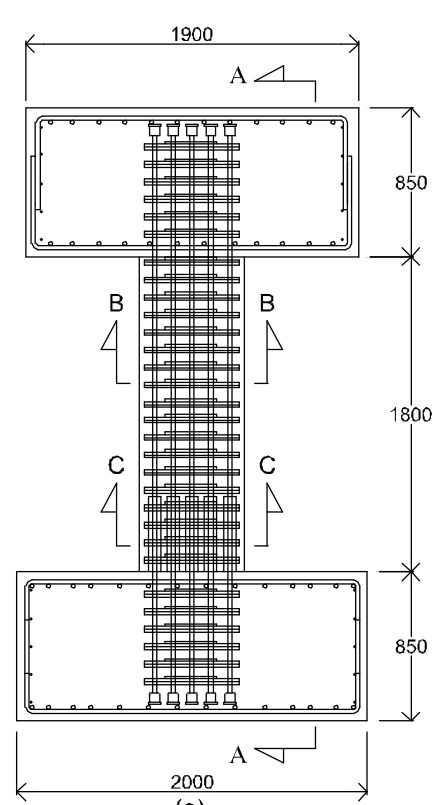

(a)

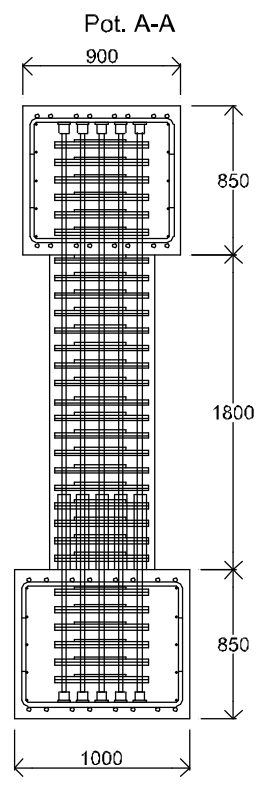

(b)

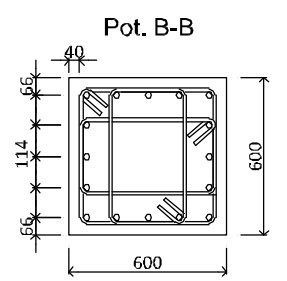

Tul. longitudinal : 16D25

Tul. transversal : D13-100

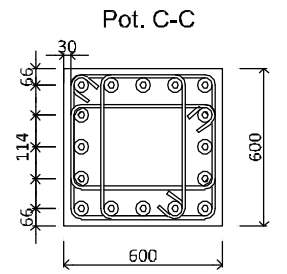

Tul. longitudinal : 16D25

Tul. transversal : D13-100

(c)

Gambar 1. Detail geometri kolom: (a) tampak depan; (b) tampak samping; dan (c) potongan melintang kolom.

dan selongsong kopler baja. Saat ini, berbagai penelitian secara eksperimental maupun analitik telah dilakukan untuk menginvestigasi sambungan tipe ini pada penerapannya di zona seismik tinggi [1], [3], [5]-[7]. Hasil menunjukkan bahwa perkembangan kerusakan dan mekanisme sendi plastis terjadi saat sambungan GS digunakan pada elemen beton pracetak. Kekuatan dan kekakuan spesimen beton pracetak ditemukan serupa atau hanya sedikit berbeda dari spesimen monolit tanpa GS [1], [5]

Pada penelitian ini, akan disimulasikan pembebanan statik-monotonik pada kolom beton pracetak dengan kelengkungan ganda serta sambungan GS menggunakan rangkaian program internal 3DNLFEA. Terdapat satu spesimen yang dimodelkan pada penelitian ini, model diperoleh dari pengujian eksperimen kolom berskala penuh pada penelitian [1] yaitu GH10. Model konstitutif plastisitas beton di bawah tekan didasarkan pada [8]. Tegangan tarik beton dengan model kegagalan Rankine ditambahkan pada model konstitutif [9] dan perilaku selimut beton di bawah perilaku pengekangan aktif dan pasif juga disediakan model konstitutif ini [10]. Sedangkan model konstitutif untuk pelat baja didasarkan pada Von-Mises (plastisitas J2).

Hasil analisa difokuskan melalui perbandingan hasil kurva beban-perpindahan antara hasil pemodelan program dengan hasil eksperimen. Investigasi dilakukan pada perilaku seismik kolom meliputi pola keretakan yang terjadi, pelelehan tulangan longitudinal, pelelehan tulangan transversal, hancurnya selimut beton, dan kegagalan tulangan transversal. Apabila telah didapatkan kesesuaian hasil yang baik antara perilaku model dengan eksperimen, panjang sendi plastis dapat dianalisa pada penelitian yang akan mendatang agar kerusakan pada daerah sendi plastis beton pracetak dapat diminimalisir.

\section{Metode}

\subsection{Model Geometri}

A. Detail Kolom

Pada penelitian ini dimodelkan satu kolom mutu tinggi dengan kelengkungan ganda. Kolom tersebut merupakan kolom pracetak berskala penuh yang diambil dari eksperimen oleh [1] yaitu kolom GH10. Inisial "G" menunjukkan penggunaan sambungan mekanis berupa grouted sleeve (GS) pada daerah sendi plastis untuk sambungan kolom ke pondasi, "H" menunjukkan tulangan transversal dengan kait, dan "10" menunjukkan beban aksial rendah yang diterapkan pada penelitian tersebut yaitu $0.1 \mathrm{~A}_{\mathrm{g}} \mathrm{f}^{\prime}$. Detail geometri dan konfigurasi tulangan disajikan pada Gambar 1. Penampang kolom adalah persegi dengan ukuran lebar $600 \mathrm{~mm}$ dan tinggi $1800 \mathrm{~mm}$. Dimensi penampang blok beton di atas dan di bawah ujung kolom masing-masing adalah 900x1900 mm dan 900x2000 mm, sedangkan keduanya memiliki tinggi yang sama yaitu $850 \mathrm{~mm}$. Selimut beton pada kolom dan blok beton masing-masing adalah $43 \mathrm{~mm}$ dan $40 \mathrm{~mm}$. Kuat tekan beton yang digunakan yaitu $74 \mathrm{MPa}$. 


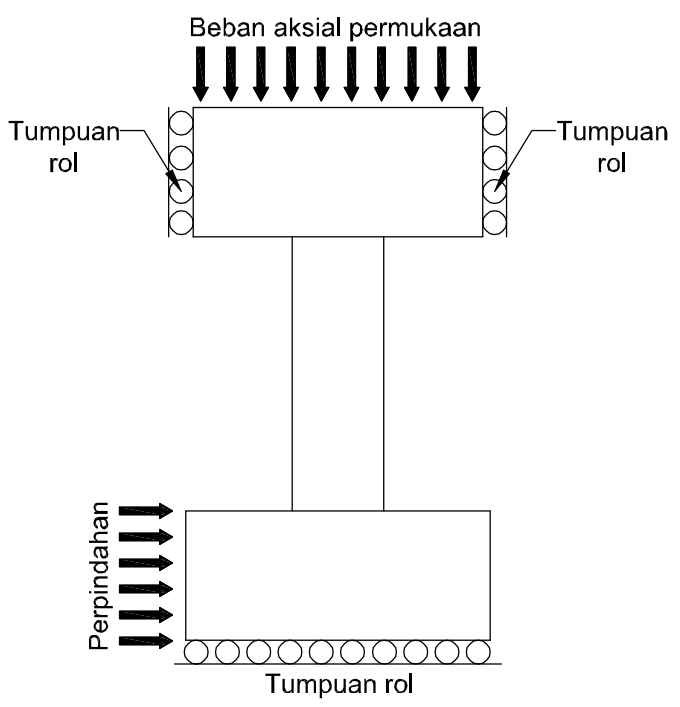

(a)

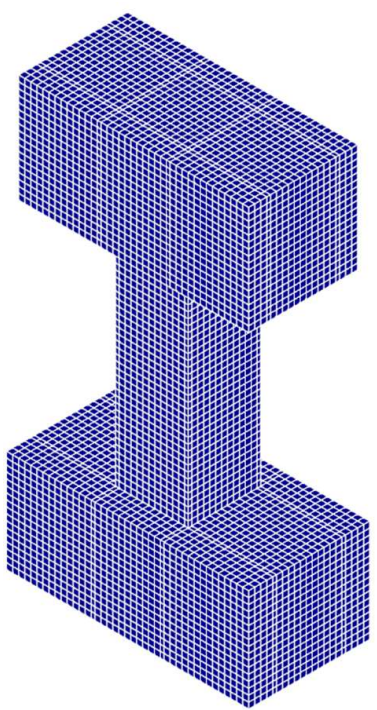

(b)

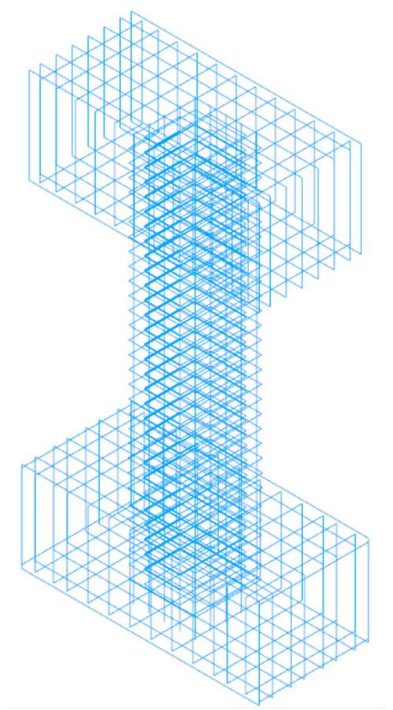

(c)

Gambar 2. Penerapan kondisi batas kolom: (a) penerapan beban-perpindahan; (b) meshing kolom pada SALOME; dan (c) penulangan kolom pada program SALOME.

\section{B. Simplifikasi Model GS}

Penyederhanaan model geometri GS pada penelitian ini diadopsi dari Haber [11] . Pengaruh deformasi akibat bondslip dihadirkan pada model sebagai akibat adanya rotasi akibat pemasangan GS [11]. Dua jenis tulangan longitudinal digunakan untuk merepresentasikan GS. Detail desain disajikan pada Gambar 3. Bagian "B1" digunakan sebagai representasi tulangan longitudinal di luar GS, sedangkan "B2" untuk wilayah di dalam GS. Keduanya memiliki luas penampang tulangan dan mutu yang sama yaitu SD685 dengan diameter $25 \mathrm{~mm}$. Untuk memperhitungkan penggunaan GS maka pada bagian B2 tulangan akan diberikan efek tekan dari beton yang akan diuraikan pada bagian selanjutnya.

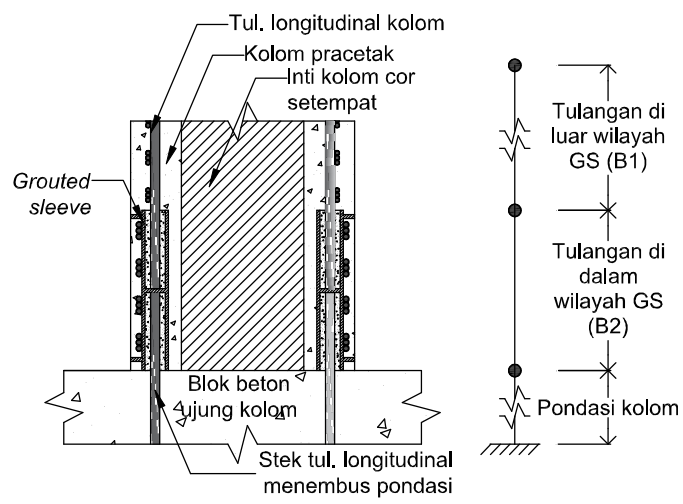

Gambar 3. Detail penyederhanaan model GS.

\subsection{Kondisi Batas}

Pada penelitian ini pembebanan yang diterapkan yaitu kombinasi beban aksial konstan dan beban lateral statik monotonik-inkremental. Penerapan beban dibagi menjadi dua tahap. Pada tahap pertama kolom akan menerima beban aksial sebesar $0,1 \mathrm{~A}_{\mathrm{g}} \mathrm{f}_{\mathrm{c}}$ atau $2.664 \mathrm{kN}$ secara inkremental, adapun penerapannya pada program 3DNLFEA yaitu dibagi menjadi 20 tahap. Beban aksial diberikan pada permukaan pelat baja sebagai media transfer beban. Kemudian pada tahap kedua, beban aksial diterapkan secara konstan sementara perpindahan diberikan pada kolom sebesar 4\% dari simpangan secara inkremental. Perpindahan diberikan melalui sisi samping blok beton bawah. Adapun, riwayat pembebanan pada tahap kedua disajikan pada Gambar 4.

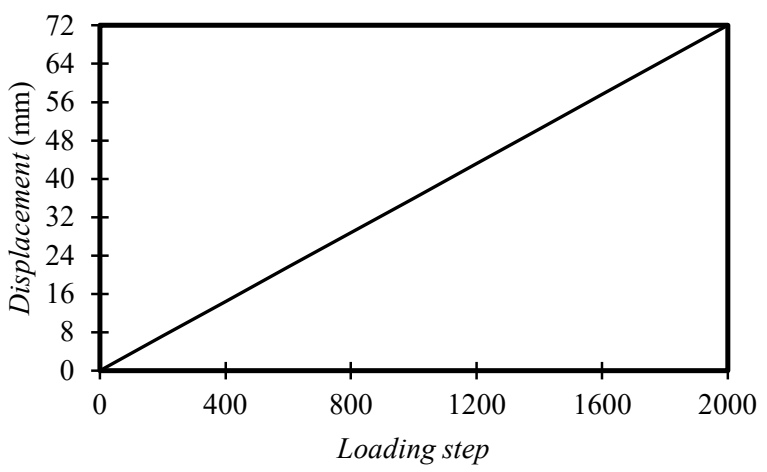

Gambar 4. Grafik pembebanan lateral monotonik. 
Kolom diberi tumpuan rol pada kedua sisi kanan dan kiri blok beton atas dan sisi dasar blok beton bawah [12]. Kondisi batas yang diterapkan disajikan pada Gambar 2(a).

\subsection{Properti Material dan Konstitutif Material}

A. Tulangan Baja Mutu Tinggi

Kolom di desain dengan tulangan mutu tinggi menggunakan SD685 untuk tulangan longitudinal dan SD785 untuk tulangan transversal, sedangkan pada blok beton digunakan tulangan mutu normal SD420 dengan diameter $16 \mathrm{~mm}$. Rasio tulangan longitudinal ditentukan 2,18\%, digunakan 16 tulangan longitudinal D25 mm. Sedangkan rasio tulangan transversal yang adalah $2 \%$, digunakan tulangan transversal empat kaki D13 mm. Detail properti tulangan dicantumkan dalam Tabel 1. Adapun kurva tegangan-regangan tulangan baja disajikan pada Gambar 5 dan 6.

Tabel 1. Detail Properti Tulangan Baja

\begin{tabular}{ccc}
\hline Jenis/ Properti & $\begin{array}{c}\text { Tegangan } \\
\text { leleh, } f_{y} \\
(\mathrm{MPa})\end{array}$ & $\begin{array}{c}\text { Tegangan } \\
\text { ultimit, } f_{u} \\
(\mathrm{MPa})\end{array}$ \\
\hline Tulangan longitudinal SD685 & 713 & 932 \\
Tulangan transversal SD 785 & 886 & 1.095 \\
Tulangan longitudinal SD420 & 420 & 600 \\
\hline
\end{tabular}

Sumber: [1]

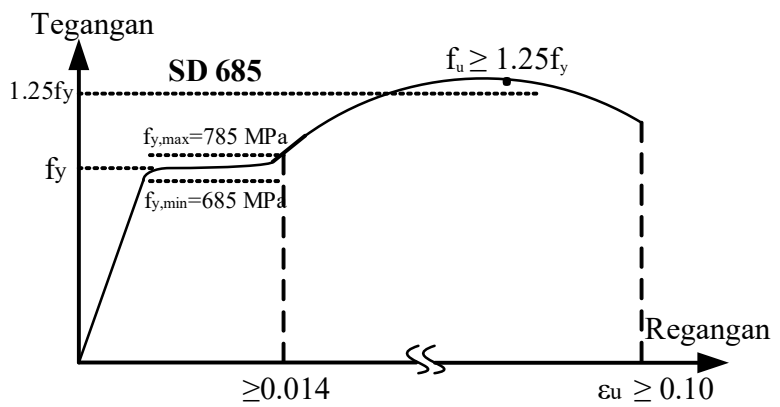

Gambar 5. Kurva tegangan-regangan SD685.

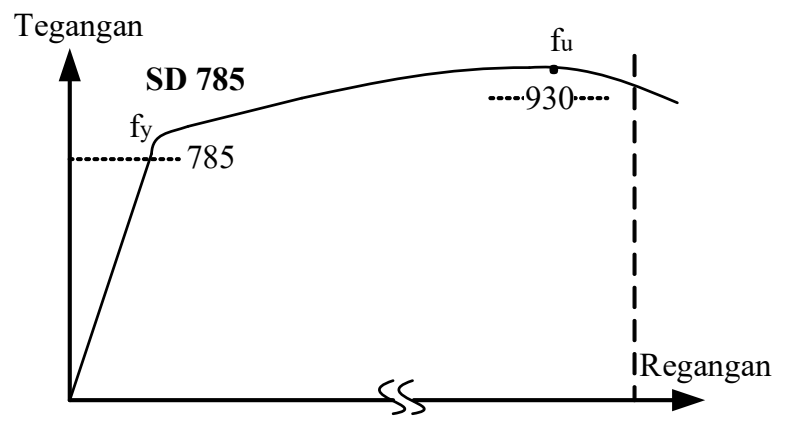

Gambar 6. Kurva tegangan-regangan SD785.

Model konstitutif tulangan baja pada penelitian ini disederhanakan melalui properti "UNSYM" (asimetri dengan tekuk) yang tersedia dalam 3DNLFEA dimana terdapat kurva tegangan-regangan pada kondisi tarik dan tekan. Tulangan longitudinal itu sendiri dibagi menjadi dua bagian, yaitu di dalam GS dan di luar wilayah GS. Adapun gambar kurva tegangan-regangan sebagai input pada 3DNLFEA disajikan pada Gambar 9.

B. Beton Mutu Tinggi

Beton mutu tinggi merupakan material beton yang direncanakan lebih dari $55 \mathrm{MPa}$ (ACI Comitte 363). Berdasarkan Taiwan Concrete Institute didapat bahwa definisi beton mutu tinggi adalah beton yang memiliki mutu $70-100$ $\mathrm{MPa}$. Sehingga dapat dipastikan bahwa batasan beton mutu tinggi untuk tiap daerah akan berbeda-beda. Namun terdapat dua perbedaan penting antara beton mutu tinggi dan beton mutu normal. Pada beton mutu tinggi ikatan partikel agregat lebih kuat daripada beton normal. Apabila retak terjadi pada beton mutu normal maka terjadi lepasnya ikatan antara pengikat dan agregatnya. Retak yang terjadi pada beton mutu tinggi dapat terjadi lebih halus daripada retak beton mutu normal karena retak bisa terjadi dengan membelah agregat tanpa lepas dari pengikatnya. Perbedaan kedua dapat dilihat dari hubungan tegangan-regangan beton. Beton mutu tinggi menghasilkan kekakuan lebih tinggi dibandingkan beton mutu normal. Kurva pasca beton mencapai tegangan aksial tekan maksimum pada beton mutu tinggi lebih curam dibandingkan beton mutu normal, hal ini sebagaimana disajikan pada Gambar 7.

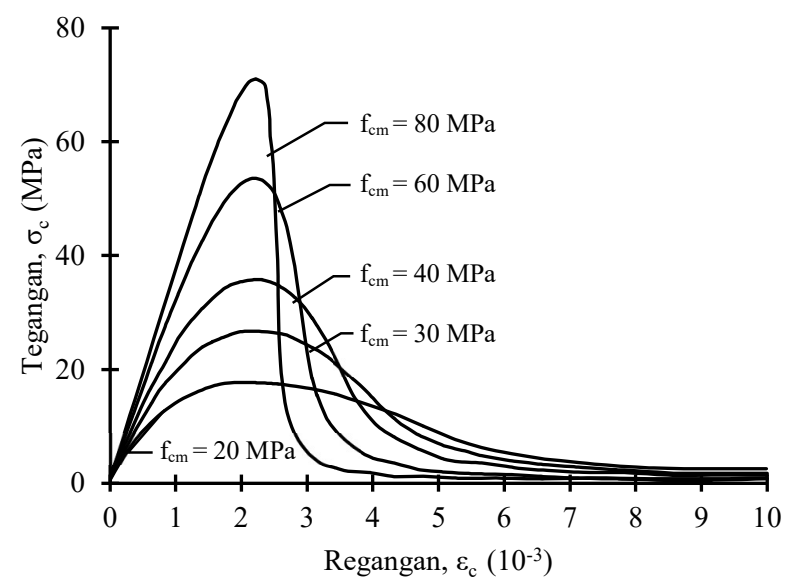

Gambar 7. Perbandingan kurva tegangan-regangan beton mutu tinggi dan mutu normal berdasarkan CEB-FIB MC90 [13].

Sebagaimana disebutkan sebelumnya, mutu beton yang digunakan pada penelitian ini adalah $74 \mathrm{MPa}$. Model konstitutif plastisitas untuk material beton terkekang di bawah tekan didasarkan pada [8], adapun model tersebut disajikan pada Gambar 8. Model konstitutif plastisitas beton 
didasarkan pada kegagalan permukaan yang dapat ditulis sebagai persamaan 1 .

$$
f(\rho, \varepsilon, \theta)=\left(\frac{\sqrt{1,5} \rho}{f_{c}^{\prime} q_{n}(k)}\right)^{2}+m \alpha\left[\frac{\rho}{\sqrt{6} f_{c}^{\prime} q_{n}(k)} r(\theta, e)+\frac{\xi}{\sqrt{3} f_{c}^{\prime} q_{n}(k)}\right]-q_{s}(k) \leq 0
$$

dimana $f c^{\prime}$ adalah kuat tekan uniaksial beton; $k$ adalah parameter hardening; $q_{h}(k)$ adalah fungsi hardening; $q_{s}(k)$ adalah fungsi softening; $r(\theta, e)$ adalah fungsi ellips; $e$ adalah eksentrisitas; $m$ adalah parameter friksi; $a$ adalah poros parameter friksi; dan $(\rho, \xi, \theta)$ adalah koordinat silinder.

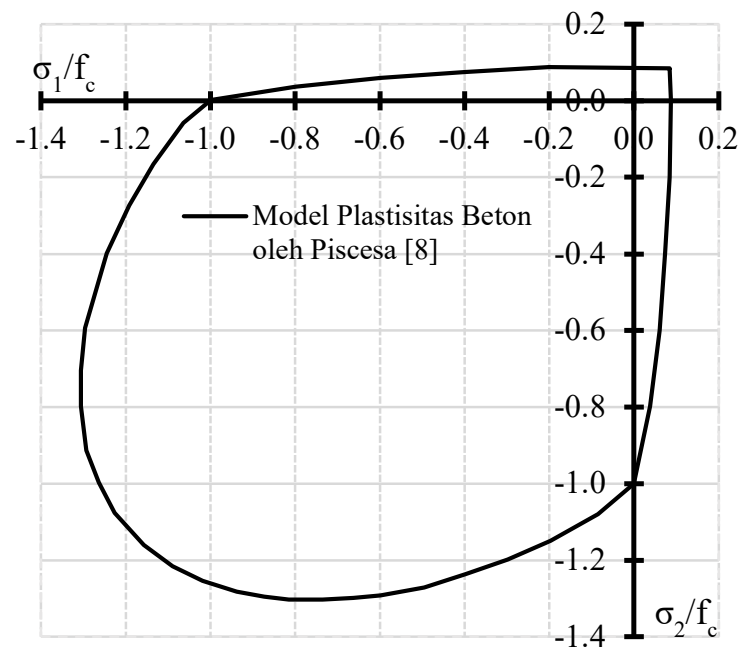

Gambar 8. Model plastisitas beton oleh Piscesa [8].

Pembaruan parameter pada formulasi untuk memprediksi tegangan puncak dan tegangan sisa beton terkekang secara rinci oleh Piscesa [8]. Laju pembesaran plastisitas yang merupakan salah satu fungsi terpenting dalam model ini yang secara langsung dikontrol dari fungsi potensial plastis dimana laju non-konstan digunakan untuk menginvestigasi keruntuhan dari pori struktur [10]. Peristiwa ini biasanya disebut cover spalling. Sedangkan fungsi pengerasan dan pelunakan pada model ini didasarkan pada regangan volumetrik plastis. Fungsi pelunakan mengikutsertakan skala panjang internal untuk menghitung efek dari ukuran elemen dimana pada penerapaannya digunakan pengaturan ukuran meshing.

Parameter yang mendefinikan model konstitutif beton berdasarkan uraian di atas sebagai masukkan di dalam 3DNLFEA diringkas pada Tabel 2.

\section{Model GS yang Diusulkan}

Pada penelitian ini geometri GS tidak dimodelkan, untuk memudahkan pekerjaan maka digunakan penyederhanaan model GS yang sebagian diadopsi dari [11] dan sebagian lainnya diusulkan pada penelitian ini. Bagian yang dimodelkan dari wilayah GS yaitu tulangan yang ada di dalamnya, sedangkan bagian beton di daerah tersebut dihilangkan sebesar diameter GS yang digunakan.

Wilayah perangkat GS disebut sebagai B2 sedangkan wilayah luar GS disebut sebagai B1 (lihat Gambar 3). Ukuran tulangan yang digunakan pada kedua wilayah baik B1 maupun B2 adalah sama yaitu $25 \mathrm{~mm}$. Model kurva tegangan-regangan tulangan di dalam perangkat GS sama dengan konstitutif tulangan baja di luar wilayah GS, namun karena terdapat parameter slip yang dimasukkan ke dalam wilayah B2 maka kekakuan tulangan pada bagian tersebut akan lebih rendah dari wilayah B1. Sama halnya seperti pada Haber dkk, [11] dimana kekakuan pada wilayah B2 diskala terhadap nilai rasio regangan, strain ratio (SR).

Sebagai representasi GS, tulangan pada bagian B2 akan mengalami tekan akibat beton di dalam GS, hal ini mengakibatkan terjadinya pengurangan tegangan pada tulangan baja di bagian tersebut. Dengan kata lain, tulangan di dalam GS mengalami penurunan kemampuan atau tegangan. Rumus pendekatan yang digunakan untuk memperhitungkan besar penurunan tegangan tersebut terdapat pada (2)-(7), luasan beton dan tulangan baja yang diperhitungkan ada di dalam GS atau di wilayah kopler dengan persamaan 2.

$$
A_{c p}=n \cdot 0.25 \cdot \pi \cdot d_{c p}^{2} ; A_{s}=n \cdot 0.25 \cdot \pi \cdot d_{b a r}^{2}
$$

dimana $d_{c p}$ dan $d_{\text {bar }}$ masing-masing adalah diameter kopler aktual dan diameter tulangan baja aktual dalam GS yang digunakan. Selisih gaya tekan yang diberikan oleh beton di wilayah tulangan B2 dalam kondisi tekan dan tarik yang diperhitungkan dalam $\mathrm{kN}$ dengan persamaan 3 .

$$
\Delta F_{b a r, c}=0.85 \cdot f_{c} \cdot\left(A_{c p}-A_{s}\right)
$$

$f_{c}$ diadopsi dari Attard dkk, [14] dimana aplikatif baik untuk beton mutu normal maupun tinggi adalah sekitar $85 \%$ dari kuat tekan hasil tes silinder, sedangkan $f_{t}$ berkisar $90 \%$ dari hasil tes tarik silinder.

$$
\begin{gathered}
f_{c}=0.85 \cdot f_{s p} \\
\Delta F_{b a r, t}=0.85 \cdot f_{t} \cdot\left(A_{c p}-A_{s}\right) \\
f_{t}=0.62 \sqrt{f_{c}}
\end{gathered}
$$

Tegangan pada tulangan dalam GS baik dalam kondisi tekan maupun tarik akan mengalami penurunan, besarnya penurunan yang didasarkan dari gaya dari beton yang diterima tulangan seperti pada (3) atau (5) dihitung dengan persamaan 7.

$$
\Delta f_{b a r}=\frac{\Delta F_{b a r}}{A_{s}}
$$

dimana $A_{s}$ adalah luas tulangan aktual. 
Perhitungan nilai modulus elastisitas baja pada tulangan di dalam GS didasarkan pada perpindahan akibat slip. Sedangkan regangan yang berkontribusi adalah regangan leleh dan regangan akibat slip. Rumus pendekatan yang digunakan disajikan pada (8)-(11).

$$
\begin{gathered}
\varepsilon_{y}=\frac{f_{y}}{E_{s}} \\
\varepsilon_{\text {slip }}=\frac{\delta_{s}}{L_{c}} \\
\varepsilon_{\text {total }}=\varepsilon_{y}+\varepsilon_{\text {slip }} \\
E_{s x}=\frac{f_{y}}{\varepsilon_{\text {total }}}
\end{gathered}
$$

dimana $L_{c}$ adalah panjang kopler aktual yang digunakan. Perpindahan akibat slip tulangan, $\delta_{s}$ dalam studi ini adalah sebesar 0,6 mm, nilai tersebut ditentukan dari slip maksimum pada anchorage dan beton.

Properti material tulangan longitudinal di dalam GS yang telah dihitung menggunakan persamaan (2-11) disandingkan dengan material tulangan baja di luar GS pada Tabel 3. Sedangkan perbandingan kurva tegangan-regangan tulangan di dalam dan di luar GS dengan properti "UNSYM" disajikan pada Gambar 9. Adapun grafik tersebut merupakan usulan dalam studi ini dan bentuk penyederhanaan dari grafik stressstrain yang diperoleh dari pengujian tarik aktual pada tulangan sebagaimana disajikan pada Gambar 5. Hal ini bertujuan untuk mengurangi tingkat kesulitan numerik pada 3DNLFEA saat terjadi putus pada tulangan.

\subsection{Pemodelan Numerik}

Pada penelitian ini simulasi pemodelan dilakukan menggunakan serangkaian program 3D-NLFEA. Program ini mampu memprediksi perilaku non-linear suatu struktur secara customize yang dikembangkan oleh Piscesa [15]. Program SALOME digunakan sebagai pre-prosesor [16] dan program Paraview digunakan sebagai pos-prosesor [17], sedangkan analisa elemen-hingga tiga-dimensi dilakukan menggunakan program inti 3DNLFEA.

Program inti 3DNLFEA menggunakan Microsoft Visual C\#.Net [10]. Dalam menyelesaikan perumusan linear, program ini menggunakan Parallel Direct Sparse Solver (ParDiSo Solver) [17]. Hal yang menjadi salah satu keunikan program ini adalah mampu menyelesaikan beban di luar kesetimbangan. Efek P-Delta atau efek $2^{\text {nd }}$ order atau non linear geometri di analisa dengan formulasi Langrangian [10], [15]. Sedangkan untuk mencapai konvergensi, Tangent Stiffness Projection Method (TSLPM) digunakan [15]. Dengan penggunaan TSLPM, dalam setiap sub-iterasi non linear global pertama, inkremen perpindahan terakhir dari konvergensi sebelumnya digunakan sebagai perpindahan inkremen pertama pada inisial tahap global sehingga nodal koordinat terbaharui dengan perpindahan konvergensi dari tahap sebelumnya, oleh karena itu dalam setiap permulaan tahap penyelesaian, matriks kekakuan dipasangkan kembali dengan geometri yang terbaharui dari kondisi konvergensi terakhir [9], [10]. Dengan begitu, banyak sub-iterasi yang dapat tersimpan.

Elemen kolom dan blok beton ujung kolom dimodelkan sebagai elemen padat 8 nodal (heksahedral) sedangkan tulangan baja dimodelkan sebagai elemen rangka 2 nodal yang tertanam pada elemen beton. Ukuran mesh maksimum yang digunakan untuk elemen beton, pelat baja sebagai media transfer beban, dan tulangan baja adalah $50 \mathrm{~mm}$ seperti disajikan pada Gambar 2(b). Model GH10 memiliki total 34509 elemen heksahedral dan 7683 nodal elemen rangka yang tertanam di dalamnya. Elemen heksahedral pada program ini menggunakan teknologi elemen BBar dengan metode integrasi terpilih [18], dimana konsep ikatan sempurna digunakan antara permukaan tulangan baja dan beton.

Tabel 2. Parameter Model Konstitutif Beton

\begin{tabular}{|c|c|c|}
\hline Jenis/ Properti & $\begin{array}{c}\text { Tulangan } \\
\text { di dalam } \\
\text { GS }\end{array}$ & $\begin{array}{c}\text { Tulangan } \\
\text { di luar } \\
\text { GS }\end{array}$ \\
\hline Tegangan leleh tarik, $f_{y t}(\mathrm{MPa})$ & 685 & 570 \\
\hline $\begin{array}{l}\text { Tegangan leleh tekan, } f_{y c} \\
(\mathrm{MPa})\end{array}$ & -685 & -570 \\
\hline Modulus Elastisitas, E (MPa) & 200.000 & 105.000 \\
\hline Regangan tarik ultimit, $\varepsilon_{\mathrm{ut}}$ & 0,205 & 0,16286 \\
\hline Regangan tekan ultimit, $\varepsilon_{\mathrm{ut}}$ & $-0,205$ & $-0,16286$ \\
\hline
\end{tabular}

\begin{tabular}{lc}
\hline \multicolumn{1}{c}{ Parameter } & Nilai \\
\hline Concrete Compressive Strength & $74 \mathrm{MPa}$ \\
(FC) & $34.140 \mathrm{MPa}$ \\
Elastic Modulus (EC) & 0,2 \\
Poisson Ratio (POS) & $2.400 \mathrm{~kg} / \mathrm{m}^{3}$ \\
Density (RHO) & $50 \mathrm{~mm}$ \\
Internal Length Scale (LT) & $3,005 \mathrm{MPa}$ \\
Uniaxial Tensile Strength (FT) & 3 \\
Old Dilation Rate (TDIL) & $-0,05$ \\
BETABMIN & 0 \\
Freeze Fracture Dir. & \\
(FFRACDIR) & \\
Ratio $f_{k} / f_{t}$ (RFKFT) & 1,05 \\
$f_{t}$ Scale for Fracture Region in & \\
Compression Failure Surface & \\
(FTLT) & \\
\hline
\end{tabular}

Tabel 3. Perbandingan Properti Tulangan Baja Longitudinal di Dalam GS dan di Luar GS 


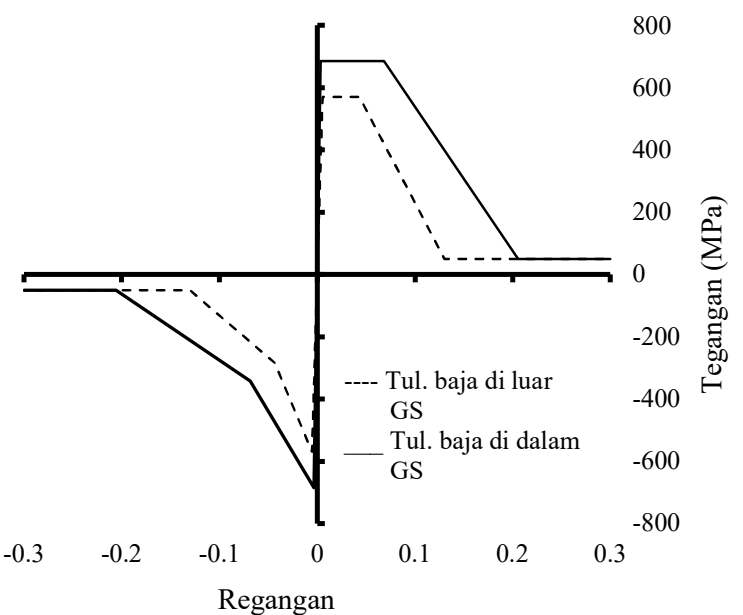

Gambar 9. Kurva tegangan-regangan tulangan baja longitudinal.

\section{Hasil dan Pembahasan}

Hasil analisa spesimen GH10 melalui program 3DNLFEA akan dievaluasi dengan hasil eksperimen pada [1] melalui grafik hubungan beban-perpindahan kolom. Grafik perbandingan beban-perpindahan yang disajikan pada [1] akibat beban siklik terbagi menjadi dua bagian, yaitu bagian dorong dan tarik, sedangkan pembebanan yang diterapkan pada penelitian ini adalah kombinasi beban aksial konstan dan statik-monotonik dimana spesimen hanya diberikan dorongan saja (pushover). Oleh karena itu, grafik beban-perpindahan dari hasil model 3DNLFEA hanya akan dibandingkan dengan grafik pada [1] bagian dorong saja. Gambar 10 menyajikan perbandingan grafik hubungan beban-perpindahan antara hasil analisa elemen-hingga tiga-dimensi dengan
3DNLFEA dengan grafik histeresis dari eksperimen pada [1]. Beberapa hal penting yang dapat dianalisa meliputi: beban puncak, pelelehan tulangan longitudinal atau trasversal, tekuk pada tulangan longitudinal, dan kegagalan fraktur dari tulangan tranversal.

Prediksi beban puncak melalui 3DNLFEA adalah sebesar $2.156,665 \mathrm{kN}$ pada nilai drift lateral 2,16\% sedangkan melalui hasil eksperimen diperoleh beban puncak aktual yaitu $2.160,984 \mathrm{kN}$ pada drift lateral $1,77 \%$. Kondisi ultimit setelah puncak beban diasumsikan sebesar $80 \%$ dari beban puncak [19]. Hasil analisa 3DNLFEA menunjukkan bahwa ultimit sebesar $1.752,98 \mathrm{kN}$ pada drift lateral 3,00\% sedangkan hasil eksperimen menunjukan kondisi ultimit pada drift lateral 3,06\%, dengan begitu program 3DNLFEA menunjukkan kesesuaian yang sangat baik dengan hasil eksperimen. Secara ringkas hasil ini disajikan dalam Tabel 4.

Tabel 4. Perbandingan Prediksi Beban Model 3DNLFEA dengan Hasil Eksperimen [1]

\begin{tabular}{lcc}
\hline \multicolumn{1}{c}{ Parameter } & $\begin{array}{c}\text { Model } \\
\text { 3DNLFEA }\end{array}$ & $\begin{array}{c}\text { Hasil } \\
\text { eksperimen } \\
{[1]}\end{array}$ \\
\hline Beban puncak (kN) & $2.156,665$ & $2.160,984$ \\
Beban ultimit $(\mathrm{kN})$ & $1.752,98$ & $1.728,29$ \\
Drift beban puncak (\%) & 2,16 & 1,77 \\
Drift beban ultimit (\%) & 3,00 & 3,06 \\
\hline
\end{tabular}

Gambar 11 (d-e) menunjukkan parameter hardening yang terjadi pada drift nominal $1,5 \%$ dan $3 \%$ untuk masingmasing hasil analisa 3DNLFEA dan hasil eksperimen, parameter hardening merupakan salah satu parameter yang menunjukkan kerusakan beton, dimana pengelupasan selimut beton terjadi saat nilai parameter ini melebihi satu [12].

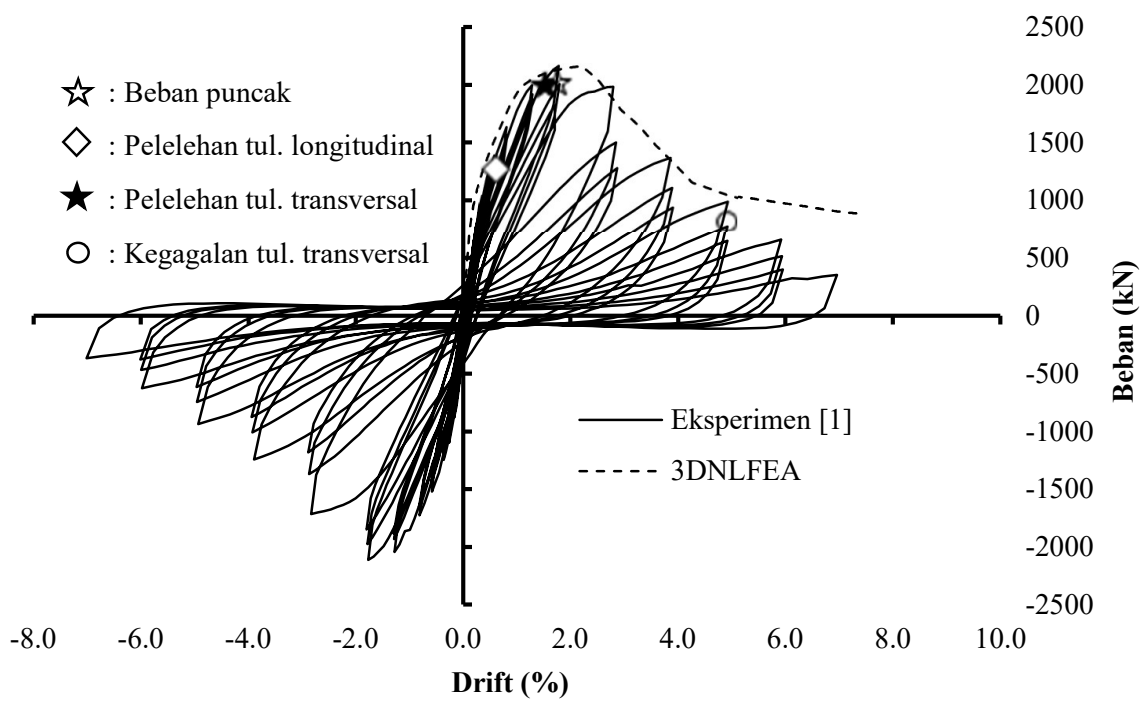

Gambar 10. Grafik hubungan beban-perpindahan pada GH10 


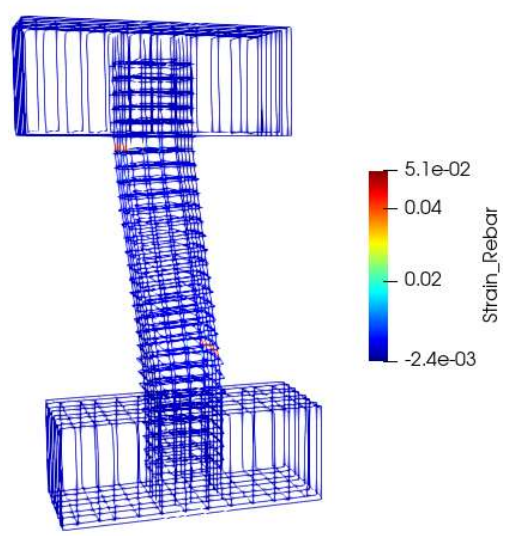

(a)

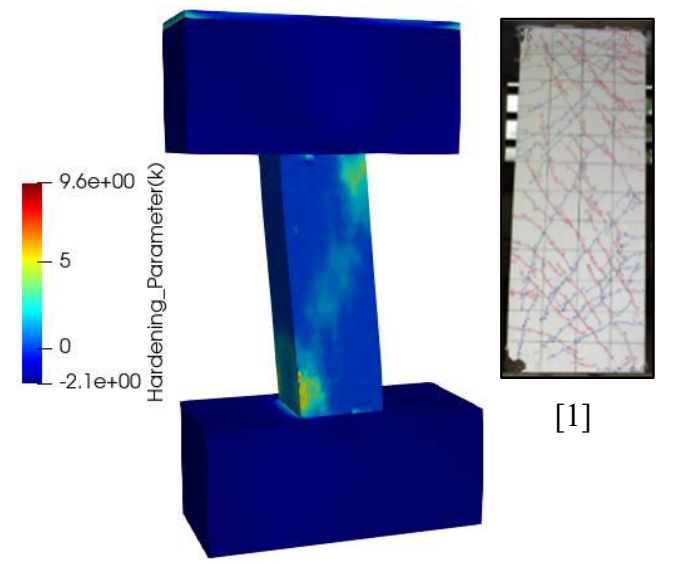

(d)

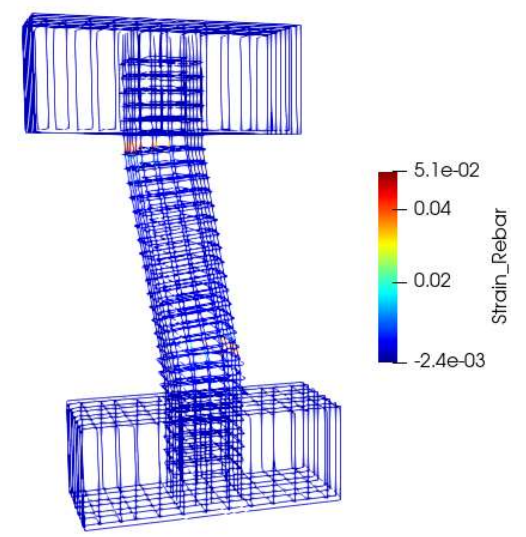

(b)

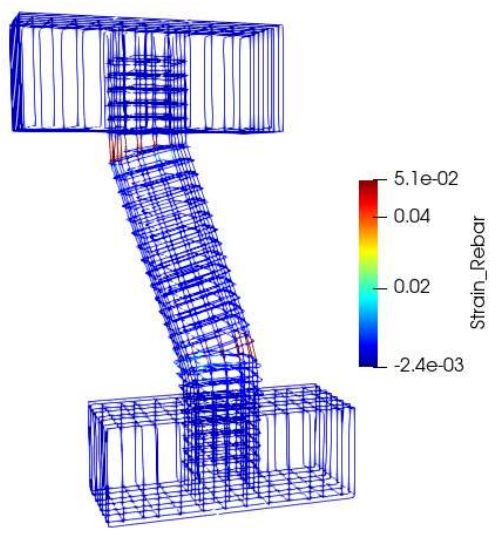

(c)

Gambar 11. Regangan tulangan pada drift nominal masing-masing: (a) $1.77 \%$; (b) $2.51 \%$; (c) $5.00 \%$ dan deformasi kolom pada: (d) drift nominal 1.5\% dan (e) drift nominal $3 \%$

Pada drift nomial 1.5\% terjadi baik retak lentur, lentur-geser, maupun retak-geser badan sepanjang kolom. Hal ini juga disertai dengan lokalisasi pengelupasan selimut beton pada bagian ujung kaki dalam kondisi tarik. Pada drift nominal 3\% lebar bukaan retak semakin membesar sepanjang kolom dan lokalisasi pengelupasan selimut beton bertambah pada bagian ujung atas kolom, bahkan pada kondisi ini terjadi pelelehan tulangan transversal karena adanya tekanan pengekangan (Gambar 11e). Namun, Gambar 11 secara keseluruhan menunjukkan bahwa kolom masih mampu memberikan tahanan bahkan setelah terjadi kerusakan pada drift nominal 3\%. Pelelehan tulangan longitudinal pertama masing-masing pada hasil analisa 3DNLFEA dan eksperimen yaitu terjadi pada drift nominal $0,60 \%$ dan $0,74 \%$.

\section{Kesimpulan}

Penelitian ini menyajikan analisa numerik perilaku kolom beton pracetak aksial rendah, $0,1 \mathrm{~A}_{\mathrm{g}} \mathrm{f}_{\mathrm{c}}$ di bawah beban kombinasi aksial tekan dan lateral statik-monotonik. Program yang digunakan adalah rangkaian program internal 3DNLFEA dimana pre-prosesor program ini adalah program SALOME dan pos-prosesornya adalah program Paraview. Elemen tipe heksahedral digunakan untuk memodelkan elemen solid beton dan baja, sedangkan tulangan baja dimodelkan sebagai rangka yang tertanam di dalam beton. Dari hasil analisis dapat disimpulkan beberapa hal sebagai berikut: 1. Hasil prediksi model menunjukkan kesesuaian yang baik dengan hasil eksperimental. Beban puncak diprediksi sebesar 2.156,665 $\mathrm{kN}$ pada nilai drift lateral 2.16\%, sedangkan dari hasil eksperimen diperoleh beban puncak aktual yaitu 2.160,984 kN pada drift lateral 1,77\%.

2. Pelelehan tulangan longitudinal dapat terlihat jelas yaitu pada kondisi drift lateral $1,77 \%$.

3. Pola retak yang terjadi dapat diprediksi dengan baik oleh program 3DNLFEA terlihat pada Gambar 11. 
4. Program 3DNLFEA secara keseluruhan memiliki kesesuaian yang sangat baik dengan hasil eksperimen, sehingga program ini dapat dikatakan valid.

$$
\begin{aligned}
& \text { Notasi } \\
& \text { Berikut ini adalah simbol yang digunakan dalam studi ini: } \\
& A_{c p} \quad=\text { luas beton di dalam GS }\left(\mathrm{mm}^{2}\right) \\
& n=\text { jumlah tulangan baja longitudinal } \\
& d_{c p}=\text { diameter GS aktual yang digunakan (mm) } \\
& A_{s} \quad=\text { luas tulangan baja longitudinal }\left(\mathrm{mm}^{2}\right) \\
& d_{\text {bar }}=\text { diameter tulangan baja longitudinal }(\mathrm{mm}) \\
& \Delta F_{b a r, c}=\text { gaya tekan beton di dalam GS dalam kondisi } \\
& \text { tekan }(\mathrm{kN}) \\
& f_{c}^{\prime}=\text { kuat tekan uniaksial beton }(\mathrm{MPa}) \\
& f_{s p} \quad=\text { kuat tekan beton hasil tes silinder }(\mathrm{MPa}) \\
& \Delta F_{\text {bar,t }}=\text { gaya tekan beton di dalam GS dalam kondisi } \\
& \text { tarik }(\mathrm{kN}) \\
& f_{t} \quad=\quad \text { kuat tarik beton yang digunakan }(\mathrm{MPa}) \\
& \Delta f_{\text {bar }}=\text { selisih tegangan pada tulangan baja akibat } \\
& \text { gaya tekan beton }(\mathrm{MPa}) \\
& \varepsilon_{y} \quad=\text { regangan leleh } \\
& f_{y} \quad=\text { kuat leleh tulangan baja longitudinal }(\mathrm{MPa}) \\
& \varepsilon_{\text {slip }} \quad=\text { regangan slip } \\
& \delta_{s}=\text { deformasi maksimum akibat slip dari } \\
& \text { penetrasi sambungan tulangan longitudinal } \\
& (\mathrm{mm}) \\
& L_{c} \quad=\text { panjang GS }(\mathrm{mm}) \\
& E_{s x}=\text { modulus elastisitas tulangan baja di dalam GS } \\
& \text { (MPa) } \\
& k=\text { parameter hardening } \\
& q_{h}(k)=\text { fungsi hardening } \\
& q_{s}(k)=\text { fungsi softening } \\
& r(\theta, e)=\text { fungsi ellips } \\
& e \quad=\text { eksentrisitas } \\
& m \quad=\text { parameter friksi } \\
& a=\text { adalah poros parameter friksi } \\
& (\rho, \xi, \theta)=\text { koordinat silinder }
\end{aligned}
$$

\section{Daftar Pustaka}

[1] Y. C. Ou, H. Alrasyid, Z. B. Haber, and H. J. Lee, "Cyclic behavior of precast high-strength reinforced concrete columns," ACI Struct. J., vol. 112, no. 6, pp. 839-850, 2015, doi: 10.14359/51687911.

[2] H. Aoyama, Design of modern highrise reinforced concrete structures, vol. 3. 2001.

[3] Z. B. Haber, M. S. Saiidi, and D. H. Sanders, "Seismic performance of precast columns with mechanically spliced column-footing connections," ACI Struct. J., vol. 111, no. 3, pp. 639-650, 2014, doi:
$10.14359 / 51686624$.

[4] S. A. Sheikih and S. S. Khoury, "Confined concrete columns with Stubs," ACI Struct. J., vol. 90, no. 4, pp. 414-431, 1993, doi: 10.14359/3960.

[5] Z. B. Haber, K. R. Mackie, and H. M. Al-Jelawy, "Testing and Analysis of Precast Columns with Grouted Sleeve Connections and Shifted Plastic Hinging," J. Bridg. Eng., vol. 22, no. 10, pp. 1-14, 2017, doi: 10.1061/(ASCE)BE.1943-5592.0001105.

[6] M. J. Ameli, D. N. Brown, J. E. Parks, and C. P. Pantelides, "Seismic column-to-footing connections using grouted splice sleeves," ACI Struct. J., vol. 113, no. 5, pp. 1021-1030, 2016, doi: 10.14359/51688755.

[7] H. M. Al-Jelawy, K. R. Mackie, and Z. B. Haber, "Shifted plastic hinging for grouted sleeve column connections," ACI Struct. J., vol. 115, no. 4, pp. 11011114, 2018, doi: 10.14359/51702233.

[8] B. Piscesa, M. M. Attard, A. K. Samani, and S. Tangaramvong, "Plasticity constitutive model for stress-strain relationship of confined concrete," $A C I$ Mater. J., vol. 114, no. 2, pp. 361-371, 2017, doi: $10.14359 / 51689428$.

[9] B. Piscesa, M. Attard, A. Samani, and P. Suprobo, "Numerical Investigation on The Behavior of Concrete-FilledSteel-Tube Column under Eccentric Loading," Third Int. Conf. Civ. Eng. Res., vol. 10, no. August 1st-2nd 2017, pp. 1-6, 2017.

[10] B. Piscesa, M. M. Attard, D. Prasetya, and A. K. Samani, "Modeling cover spalling behavior in high strength reinforced concrete columns using a plasticity-fracture model," Eng. Struct., vol. 196, no. April, p. 109336, 2019, doi: 10.1016/j.engstruct.2019.109336.

[11] Z. B. Haber, M. Saiid Saiidi, and D. H. Sanders, "Behavior and simplified modeling of mechanical reinforcing bar splices," ACI Struct. J., vol. 112, no. 2, pp. 179-188, 2015, doi: 10.14359/51687455.

[12] H. Alrasyid, M. A Rofiq, and D. Iranata, "Finite Element Analysis of Flexural Failure of High-Strength Reinforced Concrete Columns," vol. 187, no. IcoSITE, pp. 31-34, 2019, doi: 10.2991/icosite19.2019.6.

[13] CEB-FIP, “CEB_FIP_model_code_1990_ing.pdf.” p. 462, 1990.

[14] M. M. Attard and S. Setunge, "Stress-strain relationship of confined and unconfined concrete," ACI Mater. J., vol. 93, no. 5, pp. 432-442, 1996, doi: $10.14359 / 9847$

[15] B. Piscesa, "Modeling Confined Concrete Using 
Plasticity Formulation," 2018.

[16] A. Ribes, A. Bruneton, and A. Geay, SALOME: an Open-Source simulation platform integrating ParaView. 2017.

[17] U. Ayachit, The ParaView Guide: A Parallel Visualization Application. Clifton Park, NY, USA: Kitware, Inc., 2015.

[18] R. Lawther, "Modification of iterative processes for improved convergence characteristics," Int. J. Numer. Methods Eng., vol. 15, no. 8, pp. 1149-1159, 1980, doi: $10.1002 / \mathrm{nme} .1620150804$.

[19] R. Park, "Ductility evaluation from laboratory and analytical testing," Proceedings of the 9th World Conference on Earthquake Engineering, 2-9 August. pp. 605-616, 1988, doi: 1. 